\title{
経鼻チューブを使用した経管投与が ストロメクトール錠の投与量に及ぼす影響
}

\author{
金 永進 $^{1}$, 酒巻智美 ${ }^{1}$, 湯浅奈絵 $^{1}$, 吉増孝嗣 $^{1}$, 宮嶋篤志 ${ }^{2}$, 廣田孝司 ${ }^{2}$, 小茂田昌代 ${ }^{* 1}$ \\ 東京理科大学薬学部医療安全学研究室, 東京理科大学薬学部生物薬剂学研究室 ${ }^{2}$
}

\section{Influence of Using Transnasal Tubes on the Dose of STROMECTOL ${ }^{\circledast}$ Tablets}

\author{
Yonchin Kimu ${ }^{1}$, Tomomi Sakamaki ${ }^{1}$, Nae Yuasa ${ }^{1}$, Takashi Yoshimasu, \\ Atsushi Miyajima', Takashi Hirota ${ }^{2}$ and Masayo Komoda*1 \\ Department of Medical Safety, Faculty of Pharmaceutical Sciences, Tokyo University of Science ${ }^{1}$, \\ Department of Biopharmaceutics, Faculty of Pharmaceutical Sciences, Tokyo University of Science ${ }^{2}$ \\ $\left[\begin{array}{l}\text { Received February 20, } 2014 \\ \text { Accepted July 28, } 2014\end{array}\right]$
}

STROMECTOL ${ }^{\circledR}$ (ivermectin), an oral scabicide, is often administered to patients as a simple suspension via a feeding tube. It has been reported that the effectiveness of ivermectin administration via a feeding tube is dependent on the devices or techniques employed. This route of administration reduces the dose of ivermectin by $10-50 \%$ compared to that associated with oral administration. Therefore, here we propose appropriate devices and techniques.

In this report, we compared the recovery ratio when a simple suspension was administered via transnasal tubes of different diameters, different materials, flushing water volumes, slack and bed angle. No differences in recovery ratio were observed following the use of tubes constructed from polyvinyl chloride, ethylene vinyl acetate, polyurethane, and silicone. Furthermore, no significant differences in ivermectin recovery were observed as a result of using tubes with diameters of 8 French (Fr) and 12 Fr. However, we found tubes with diameters of 7 Fr were blocked during use.

Furthermore, no noticeable differences in the recovery ratio were observed after flushing water volumes higher or lower than the internal volume of the transnasal tubes. Slack in the tubes had no influence on the recovery ratio. In contrast, a $9 \%$ increase in the recovery ratio of ivermectin was observed when the patient's bed was angled at $30^{\circ}$ compared to that when the bed remained horizontal.

In conclusion, to ensure higher recovery ratios of ivermectin with administration via transnasal tubes, it is recommended that tubes with diameters over 8 Fr be used, and that an angle greater than $30^{\circ}$ be applied to the patient's bed.

Key words — scabicide, ivermectin, transnasal tubes, simple suspension method, dosage

\section{緒 言}

疥癬はヒト皮膚角質層にヒゼンダニ（疥癬虫, Sarcoptes scabiei var hominis） が寄生することで発 症する皮膚感染症である. ${ }^{1)}$ 本邦での疥癬の治療に は外用薬が用いられてきたが，全身塗布を必要と するなど医療従事者および患者の負担が大きいと いう問題があった. 加えて, $\gamma$-benzene hexachloride $(\gamma-\mathrm{BHC})$ の使用は試薬の入手も不可能となり（外 務省, 残留性有機污染物質に関するストックホル 么条約, http://www.mofa.go.jp/mofaj/gaiko/kankyo/ jyoyaku/pops.html, 2011 年 4 月 5 日）（経済産業省, ストックホルム条約第 4 回締約国会議 (COP4) の結果について, http://warp.ndl.go.jp/info:ndljp/ pid/286890/www.meti.go.jp/press/20090512001/ 20090512001.pdf', 2011 年 4 月 8 日), さらに, 最 も効果があるとされるペルメトリン外用剂 ${ }^{2)}$ は本 邦において承認されていない。一方, 本邦で経口 疥癬治療薬としての適応が承認されたストロメク トール ${ }^{\circledR}$ 錠（一般名：イベルメクチン）は，数回 の服用で高い有効性が示され ${ }^{3)}$ 利便性にも優れる ことから, 現在, 疥癬治療に繁用されている.

\footnotetext{
* 于278-8510千葉県野田市山崎2641
} 
疥癬は免疫力の低下した高齢者などに多く発症 する疾患であるため, ${ }^{4}$ 患者は経腸栄養剤を経管 投与されている場合も多いと想定される，ストロ メクトール®錠を経管投与する場合，近年では錠 剂を粉砕せずに水を用いて崩壊・懸濁させて投与 する簡易懸濁法が普及しつつある，疥癬診療ガイ ドライン（第 2 版）においても「投与直前に水に て崩壊・懸濁し, 経管投与することが可能である」 と記載されている. ${ }^{1)}$ しかし，ストロメクトール® 錠の製造販売後調査では経管投与を行った際の有 効性などに関する記載はなく, 経管投与時の有効 性は経口投与に比べて劣るとの報告もある. ${ }^{5,6}$

そこで著者らは，胃瘦チューブを用いた経管投 与時に簡易懸濁法において崩壊・懸濁する温度, 投与する注入器および投与手技の違いがストロメ クトール®錠の投与量に及ぼす影響について検討 を行った，その結果, 懸濁時の水温の影響はなく， 未洗浄の注入器の使用, 薬剤注入後に注入器内に 残存した薬剤を水 $20 \mathrm{~mL}$ で洗い，再注入する操 作（フラッシュ操作）の有無, 注入器の投与角度 の影響を受け, 約 $10 \%$ から最大約 $50 \%$ の投与量

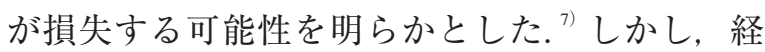
鼻チューブを使用して経管投与する際の投与量へ の影響については検証されていない，特に経鼻 チューブでは胃瘦に用いるチューブよりも細いう えに全長が長く, 投与時のベッドアップの状況に より，チューブが垂れ下がる場合もあるため，難 水溶性のイベルメクチンがチューブ内に滞留する 可能性が考えられる。 さらに，チューブの材質の 違いにより薬剤がチューブ内に付着する可能性も 考えられ，" また，チューブの太さの違いにより 閉塞する可能性もある.9 さらに，イベルメクチ ンの注射剤は市販されていないため, 中心静脈栄 養管理の患者には経鼻チューブを挿入してストロ メクトール®錠を投与する場面も想定されるた め，経鼻チューブ投与によるイベルメクチンの投 与量に与える影響を検討することは意義があると 考える，そこで本研究では，経鼻チューブを用い て簡易懸濁法でストロメクトール®錠を投与する 際の様々な状況を想定し，投与量に及ぼす影響を 明らかにすることを目的とした。

\section{方 法}

\section{1. 試薬}

イベルメクチン標準品（Lot No TSK2747）は和光 純薬工業(株) (東京)より,メタノールは関東化学(株) （東京）より購入した. イベルメクチン標準品および メタノールは高速液体クロマトグラフィー（high performance liquid chromatography: HPLC）用を用い た、ストロメクトール®錠 3 mg (Lot No NM213001) はマルホ(株) (大阪) より購入した。

\section{2. ストロメクトール ${ }^{\circledR}$ 錠の懸濁液におけるイベ ルメクチンの定量}

大谷らの報告 ${ }^{7}$ により，ストロメクトール ${ }^{\circledR}$ 錠 を水にて崩壊懸濁させ，遠心分離した上清中にイ ベルメクチンは検出できず，HPLC-UV の定量下 限值 $1 \mu \mathrm{g} / \mathrm{mL}$ 以下（0.01\%以下）であったことか ら，上清は定量せず，沈殿物をイベルメクチン全 量として定量した。

\section{HPLC-UV によるイベルメクチンの定量条件}

HPLC 装置は, システムコントローラー (Waters 600 Controller, 日本ウォーターズ(株), 東京), 送 液ユニット（Waters 600 Pump, 日本ウォーター ズ(株)，，カラムオーブン（Waters CHM，日本 ウォーターズ(株)), オートインジェクタ (Waters 2707 Autosampler, 日本ウォーターズ(株)）打よ び検出器 (Waters 2489 UV/Visible Detector, 日本 ウォーターズ(株)）を用いた，カラムは Waters Xbridge $^{\mathrm{TM}} \mathrm{C}_{18}(5 \mu \mathrm{m}, 4.6 \phi \times 150 \mathrm{~mm}$, 日本ウォー ターズ(株)）を用いた。移動相はメタノール／純 水（90:10, v/v）を用い, 測定波長を $245 \mathrm{~nm} に$ 設定した。流速は $1.0 \mathrm{~mL} / \mathrm{min}$ ，カラム温度は 40 ${ }^{\circ} \mathrm{C}$ に設定し，注入量は $20 \mu \mathrm{L}$ とした. イベルメク チンの定量は絶対検量線法により行い, 測定した データの解析に解析用ソフトウェア Empower ${ }^{\mathrm{TM}} 2$ (日本ウォーターズ(株)）を用いた。なお，ス卜 ロメクトール®錠はイベルメクチン $\mathrm{B}_{\mathrm{at}}$ とイベルメ クチン $\mathrm{B}_{\mathrm{b}}$ の混合物であるが, クロマトグラフで は保持時間 5.5 分と 4.8 分に分離され, ストロメク トール®錠 $3 \mathrm{mg} 6$ 錠（6ロット）でイベルメクチ ン $\mathrm{B}_{\mathrm{a}}$ の比率をクロマトグラムピーク面積で算出 
したところ $92.85 \pm 0.14 \%$ であり,ばらつきは小 さかった，従って，遠沈管の中でストロメクトー ル®錠 $3 \mathrm{mg}$ を温湯で崩壊懸濁させた溶液のイベル メクチン $\mathrm{B}_{\mathrm{aa}}$ の濃度を, イベルメクチン $\mathrm{B}_{\mathrm{at}}$ 標準品 の検量線を用いて定量した值を $100 \%$ として回収 率を算出した．血中動態などの分析対象はすべて イベルメクチン $\mathrm{B}_{1 \mathrm{a}}$ で行われていることから，本 研究ではイベルメクチン $\mathrm{B}_{\mathrm{la}}$ のみを定量した。主 薬の安定性については，インタビューフォームに $25^{\circ} \mathrm{C}$ で 18 カ月間安定とあり（医薬品インタビュー フォーム ストロメクトール®錠 $3 \mathrm{mg}$, マルホ株式 会社，改訂日付 2012 年 6 月)，ストロメクトール ${ }^{\circledR}$

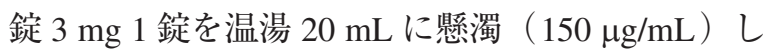
た試料 $(\mathrm{n}=3)$ を 24 時間後, 48 時間後にイベル メクチンの測定をした結果は, $150 \pm 1.1,150 \pm 1.3$ $\mu \mathrm{g} / \mathrm{mL}$ であり, イベルメクチンの濃度が保たれて いることから，通常の簡易懸濁操作における主薬 の安定性には問題がないと考えられた。

\section{4. 人形を使った投与条件の設定}

図 1 に示すように実際の患者を想定した人形 (薬学用実習シミュレータ「薬学さくら」, (株)京 都科学, 東京) に経鼻チューブを挿入し，静脈経 腸栄養ガイドラインで推奨されている経鼻経管栄 養投与方法に則り, 人形の上半身を約 $30^{\circ}$ ベット アップを行い枕で頭部を支えた. ${ }^{10,11)}$ 使用する経 鼻チューブの長さはチューブの先端位置が胃, 空 腸の双方に利用できるため, 一般に広く用いられ

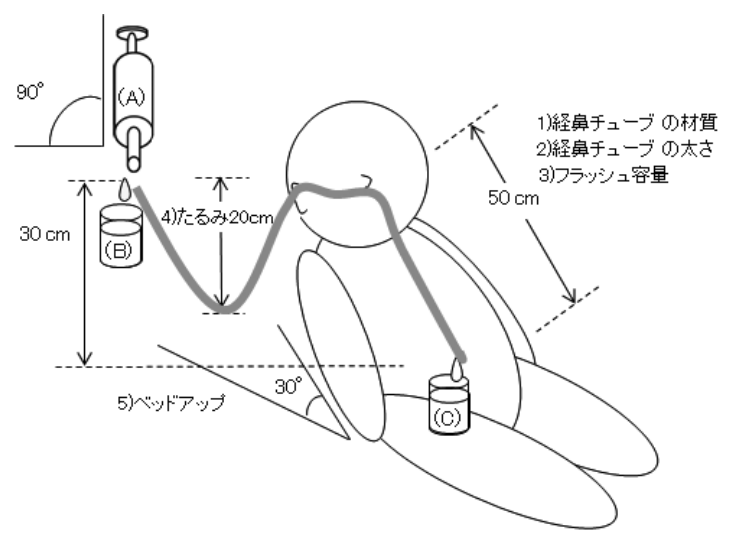

図 1 人形を使った投与条件の設定

(A）注入器・経鼻チューブを通過させずにイベルメクチンを 回収, （B）注入器を通過後のイベルメクチンを回収, (C) 注 入器・経鼻チューブを通過後のイベルメクチンを回収.
ている約 $120 \mathrm{~cm}$ に統一した. ${ }^{12)}$ チューブの端から $50 \mathrm{~cm}$ を人形に挿入し, 注入端を挿入端から 30 $\mathrm{cm}$ の高さで固定した. ${ }^{13)}$

大谷らの報告 ${ }^{7)}$ で，ストロメクトール錠を崩 壊・懸濁させ，注入器を使って投与した後（図 1 (B)）のイベルメクチン回収率についてはすでに 報告した。 今回は大谷らの報告で中口の注入器を 使用した場合の最も回収率の高い, 注入角度を真 下に向けて投与する方法を採用して, 懸濁注入操 作を行い, ${ }^{7)}$ 経鼻チューブ通過後（図１（C））の イベルメクチン回収率について定量を行った。ま ず, 注入器はテルモカテーテルチップシリンジ

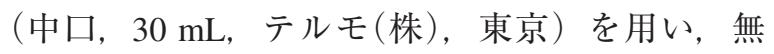
水エタノールで 6 回以上洗浄してシリコンの影響 を少なくしたものを用いた，次に，倉田式簡易眯 濁法 ${ }^{13)}$ に則り, 注入器に 3 錠のストロメクトー ル®錠 $3 \mathrm{mg}$ および $55{ }^{\circ} \mathrm{C}$ の温湯 $20 \mathrm{~mL}$ を加えて 10 分間静置した。 その後, 注入器の先端を上に 向けて $90^{\circ}$ 方向に 15 回往復横転させることで錠 剤を崩壊・懸濁させ, 経鼻チューブに接続し, 注 入器を真下に向けて懸濁液を $2 \sim 3 \mathrm{~mL} / \mathrm{sec}$ の速さ で注入した。ささらに，フラッシュ操作を精製水 $20 \mathrm{~mL}$ で同様に 1 回 2 3 mL/sec の速さで行った. 5 - (3) 以外については同様のフラッシュ操作を 行うことを前提とした。 なお，経鼻チューブは， ポリ塩化ビニル製はニプロ栄養カテーテル（8お よび $12 \mathrm{Fr}, 1200 \mathrm{~mm}$ 、ニプロ(株), 東京）を, エチレン酢酸ビニル製はニプロ EVA 経腸栄養カ テーテル（8 Fr, $1200 \mathrm{~mm}$ ，ニプロ(株)）を，ポ リウレタン製は滅菌済コーフローフィーディング チューブ (8 および $12 \mathrm{Fr}, 1220 \mathrm{~mm}$, ニプロ(株)), シリコン製はニプロシリコーン経腸栄養カテーテ

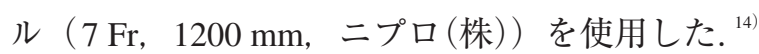
チューブ後端から回収した懸濁液および洗浄液 （図１（C)）の沈殿物中のイベルメクチン濃度を前 述の方法 2 および 3 により測定し, 投与量 (図 1(A)) を 100\%としてイベルメクチン回収率を算出した.

\section{5. イベルメクチンの投与量に影響を及ぼす経鼻 チューブを用いた経管投与方法の検討}

(1) 経鼻チューブの材質による回収率への影響 経管チューブの材質として, 市販されている胃 
瘦チューブの材質割合では柔らかいシリコンが約 70\%を占める. 一方, 経鼻チューブでは挿入が容 易で安価であるが消化液による変性を受けやすい ため短期使用されるポリ塩化ビニルが約 $49 \%$ と最 も多く，シリコンは約 25\%，ポリウレタンは約 16\% 市販されている. ${ }^{15)}$ そこで, この 3 種に加えて, ポ リ塩化ビニルの欠点を改良した可塑剤フリーの軟 質ポリ塩化ビニル製品であるエチレン酢酸ビニル も加え, 4 種の材質の経鼻チューブにおけるイベル メクチン回収率を比較した。なお, ポリ塩化ビニル, エチレン酢酸ビニル，ポリウレタン製は $8 \mathrm{Fr}$ を、シ

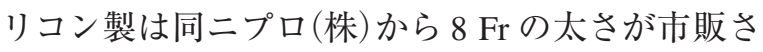
れていないため $7 \mathrm{Fr}$ を使用した.

(2) 経鼻チューブの太さによる回収率への影響

経鼻チューブは腸閉塞などの際に消化管減圧の ために用いられるチューブとは異なり，ある程度 長期間留置されるため成人患者では外径 8 12 Fr のチューブが繁用されている. ${ }^{12)}$ そこでポリ塩化 ビニル製 $8 \mathrm{Fr}$ と $12 \mathrm{Fr}$ の太さの経鼻チューブにお けるイベルメクチン回収率を比較した。

(3) フラッシュ操作の洗浄水容量による回収率へ の影響

ポリ塩化ビニル製経鼻チューブ（12 Fr，内容 積 $6.9 \mathrm{~cm}^{3}$ ) を使用し, $20 \mathrm{~mL}$ (チューブの内容積 以上）および $5 \mathrm{~mL}$ （チューブの内容積未満）の 洗浄水でフラッシュ操作をそれぞれ 5 回行った 場合のイベルメクチン回収率を比較した。なお, それぞれの操作の後に, 全量確認のため $20 \mathrm{~mL}$ のメタノールでフラッシュ操作を行った。

(4) 経鼻チューブのたるみによる回収率への影響

経鼻チューブは経腸栄養を投与する際，チュー ブのたるみが発生する場合がある。最も落差が大 きいたるみが発生する状況を検討したところ, 経 腸栄養バッグから布団まで下がった後に耳まで上 がっていく落差 $20 \mathrm{~cm}$ 程度のたるみ（図 1）ができ る可能性があることがわかった. そこで, 経鼻チュー ブを耳の後ろから $20 \mathrm{~cm}$ 程の落差を設けたたるみ がある場合とたるみがない場合におけるイベルメク チン回収率を比較した。なお，材質はポリ塩化ビニ ル製で太さ $12 \mathrm{Fr}$ の経鼻チューブを使用した.

(5)ベッドアップの有無による回収率への影響

経鼻経管栄養投与時は, 誤嚥を防ぐために坐位
ができる患者は $90^{\circ}$ のベッドアップを, 坐位がで きない患者は $30^{\circ}$ のベッドアップが推奨されてい る. ${ }^{10,11)}$ 今回は坐位ができない患者を想定し， $30^{\circ}$ のベッドアップがイベルメクチン回収率に与える 影響を検討するため, ベッドアップなしと $30^{\circ}$ ベッドアップを行った際のイベルメクチン回収率 を比較した. なお, 経鼻チューブはポリ塩化ビニ ル製で太さ $12 \mathrm{Fr}$ を使用した。

\section{6. 統計解析}

検定は全て両側検定とし, 有意水準は 5\%とし た. 方法 5-(1)の比較における有意差検定は Turkey 型多重検定を行い, 方法 5- (2)〜 (5) の比 較は Student- $t$ 検定により行った.

\section{結 果}

\section{1. 経鼻チューブの材質による回収率への影響}

図 2 に示すように, ポリ塩化ビニル, エチレ ン酢酸ビニル, ポリウレタン, シリコンの 4 種の 材質の経鼻チューブ投与後のイベルメクチン回収 率は，それぞれ $82.0 \pm 10.2 \% ， 83.3 \pm 10.1 \%$, $86.6 \pm 8.0 \%$ および $80.5 \pm 12.9 \%$ であり, 全群に おいて有意差は認められなかった $(P>0.05)$. た だし， $7 \mathrm{Fr}$ シリコン製チューブにのみ，懸濁液投 与直後に閉塞が生じた。

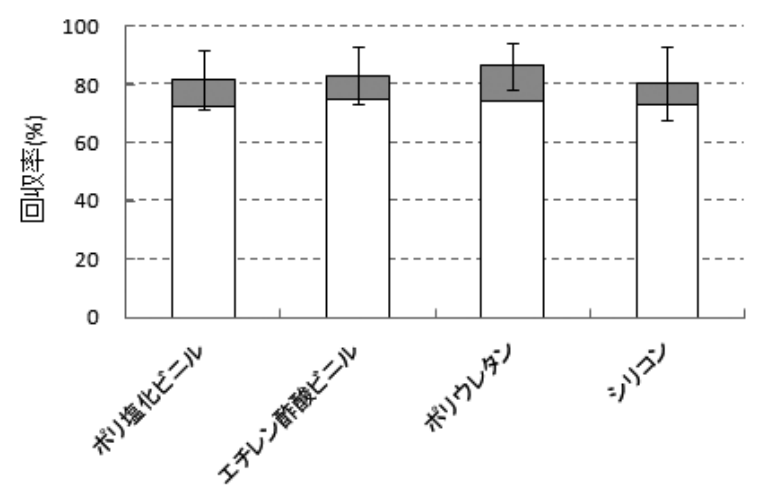

図 2 経鼻チューブの材質の影響

ポリ塩化ビニル, エチレン酢酸ビニル, ポリウレタンおよびシ リコン製経鼻チューブを用いた場合のイベルメクチン回収率 を比較した。なお，太さはポリ塩化ビニル / $8 \mathrm{Fr}$, シリコン / 7 Fr，ポリウレタン / 8 Fr およびエチレン酢酸ビニル / 8 Fr で長 さは約 $120 \mathrm{~cm}$ の経鼻チューブを使用した， $\square$ 懸濁液, $\square$ 洗浄 液. $(n=6$, 平均 \pm 標準偏差 $)$. 


\section{2. 経鼻チューブの太さによる回収率への影響}

図 3 に示すように 8 Fr の経鼻チューブ投与後 のイベルメクチン回収率は $82.0 \pm 10.2 \%, 12 \mathrm{Fr}$ では $89.1 \pm 4.5 \%$ となり，8 Fr で約 7\%回収率低 下がみられたが，有意差は認められなかった（P $>0.05)$

\section{3. フラッシュ操作の洗浄水容量による回収率へ の影響}

図 4 に示すように, 洗浄水の容量 $20 \mathrm{~mL}$ (チュー ブの内容積以上) のフラッシュ操作を 5 回行った 場合のイベルメクチン回収率は 1 回目 $90.9 \pm$ $4.5 \%, 2$ 回目 $92.5 \pm 4.3 \%, 3$ 回目 $93.0 \pm 4.2 \%$,

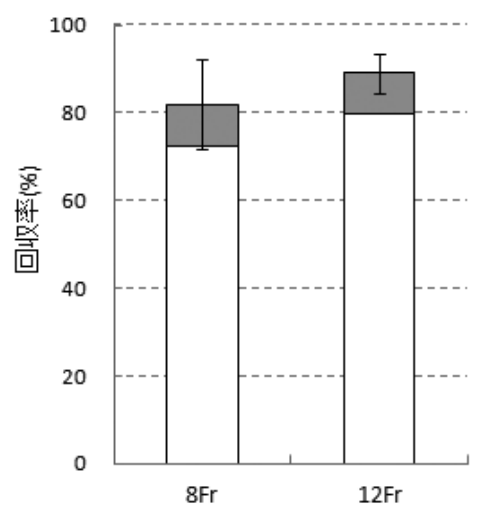

図 3 経鼻チューブの太さの影響

$8 \mathrm{Fr}$ および $12 \mathrm{Fr}$ の経鼻チューブを用いた場合のイベルメクチ ン回収率を比較した。なお，材質はポリ塩化ビニル，長さは $120 \mathrm{~cm}$ の経鼻チューブを使用した， $\square$ 懸濁液， $\square$ 洗浄液.（n $=6$, 平均 \pm 標準偏差, $P>0.05$ (洗浄後)).

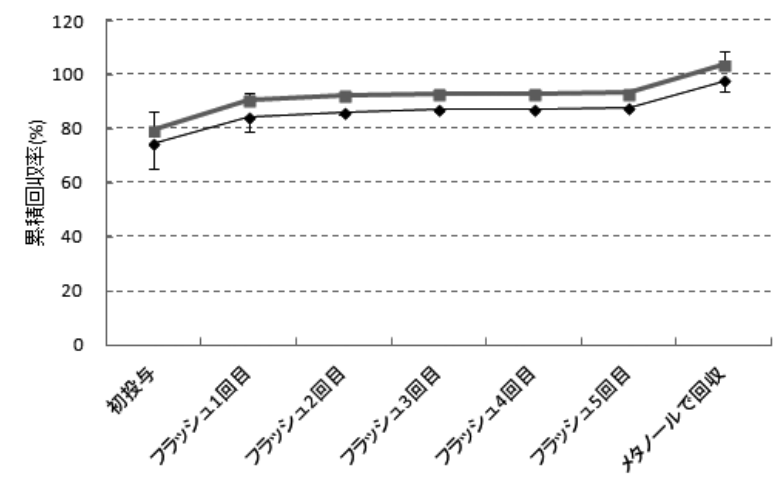

図 4 フラッシュ洗浄水の容量の影響

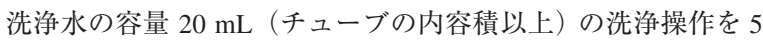
回と洗浄水の容量 $5 \mathrm{~mL}$ の洗浄操作 (チューブの内容積未満) を 5 回行った場合の回収率を比較した。なお，材質はポリ塩化 ビニル製，太さは $12 \mathrm{Fr}$ で長さは $120 \mathrm{~cm}$ の経鼻チューブ（内 容積 : $\left.6.9 \mathrm{~cm}^{3}\right)$ を使用した。 $020 \mathrm{~mL}, \diamond 5 \mathrm{~mL} . \quad(\mathrm{n}=6$, 平均 \pm 標準偏差, $P>0.05$ (洗浄後)).
4 回目 $93.2 \pm 4.2 \%, 5$ 回目 $93.4 \pm 4.2 \%$ あっあた. その後, メタノール $20 \mathrm{~mL}$ のフラッシュ操作を 行い, 回収率は $104.4 \pm 4.2 \%$ であった。洗浄水 の容量 $5 \mathrm{~mL}$ のフラッシュ操作 (チューブの内容 積未満）を 5 回行った場合のイベルメクチン回収 率は 1 回目 $84.5 \pm 7.9 \%, 2$ 回目 $86.4 \pm 7.5 \%, 3$ 回目 $87.0 \pm 7.2 \%, 4$ 回目 $87.5 \pm 7.0 \%, 5$ 回目 $87.8 \pm 6.9 \%$ であり, 約 6\%回収率は低下したが 有意差は認められなかった $(P>0.05)$. その後, メタノール $20 \mathrm{~mL}$ のフラッシュ操作を行い, 回 収率は $98.1 \pm 5.9 \%$ であった。

\section{4. 経鼻チューブのたるみによる回収率への影響}

経鼻チューブをたるませない場合のイベルメク チン回収率は $90.9 \pm 4.5 \%$, 経鼻チューブをたる ませた場合においては $90.3 \pm 2.9 \%$ となり有意差 は認められなかった $(P>0.05)$.

\section{5. ベッドアップの有無による回収率への影響}

図 5 に示すように, ベッドアップなしの場合 のイベルメクチン回収率は $81.7 \pm 6.2 \%$ であり, 30 ○ベッドアップありの場合の $90.9 \pm 4.5 \%$ に比 べて 9.2\%有意に低かった $(P<0.05)$.

\section{考察}

本研究は，簡易懸濁法によるストロメクトール® 錠の適切な経鼻チューブを使用した経管投与手技 の確立を目的とした。表 1 に示すように大谷ら ${ }^{7}$

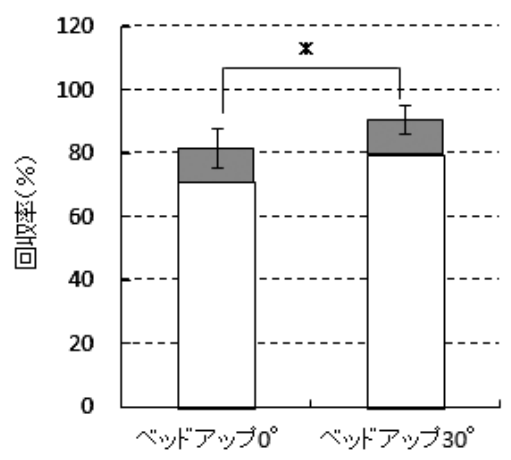

図 5 ベッドアップの有無の影響

ベッドアップを行わない場合と $30^{\circ}$ のベッドアップを行った場 合の回収率を比較した。なお，材質はポリ塩化ビニル製，太さ は $12 \mathrm{Fr}$ で長さは $120 \mathrm{~cm}$ の経鼻チューブを使用した. $\square$ 懸濁液, $\square$ 洗浄液. $\left(\mathrm{n}=6\right.$, 平均 \pm 標準偏差, ${ }^{*} P<0.05$ (洗浄後) ). 
表 1 経管投与におけるイベルメクチン投与量への影響

\begin{tabular}{|c|c|c|c|c|}
\hline & 検討項目 & 検討対象 & 投与量の最大損失率 & 比較対象（推奨） \\
\hline \multirow{5}{*}{$\begin{array}{l}\text { 経鼻 } \\
\text { チューブ }\end{array}$} & 材質 & $\begin{array}{l}\text { ポリ塩化ビニル, } \\
\text { エチレン酢酸ビニル, } \\
\text { ポリウレタン, シリコン }\end{array}$ & 13〜19 \%有意差なし & ポリウレタン 13 \% \\
\hline & 太さ & 細い（8 Fr） & $\begin{array}{l}\text { 約 } 7 \text { \%有意差なし } \\
\text { (7 Fr は閉塞) }\end{array}$ & 太い（12 Fr) \\
\hline & チューブのフラッシュ容量 ${ }^{a)}$ & $\begin{array}{l}\text { チューブ内容積未満 } \\
(5 \mathrm{~mL})\end{array}$ & 約 $6 \%$ 有意差なし & $\begin{array}{l}\text { チューブ内容積以上 } \\
(20 \mathrm{~mL})\end{array}$ \\
\hline & チューブのたるみ（落差 $20 \mathrm{~cm}$ ) & たるみあり & 有意差なし & たるみ（落差 $20 \mathrm{~cm}$ ) なし \\
\hline & ベッドアップ有無 & ベッドアップなし & 約 $9 \% *$ & $30^{\circ}$ ベッドアップ \\
\hline
\end{tabular}

a)フラッシュ洗浄水の容量(経鼻チューブ $12 \mathrm{Fr} 120 \mathrm{~cm}$ (内容積 $6.9 \mathrm{~cm}^{3}$ の場合)). *有意差あり $(P<0.05)$

の注入器の洗浄有無やフラッシュ操作有無, 投与 角度の報告を基に回収率の損失を $10 \%$ と最も抑 えることができる推奨デバイス（注入器は中口） や投与角度において, 経鼻チューブを通して投与 する際の投与量に与える影響を検討した。

まず，経鼻チューブの材質については，エカべ トナトリウム顆粒 (商品名：ガストローム® 顆粒) のようにチューブの材質の違いにより薬剤が チューブ内に付着する例 ${ }^{8}$ が報告されている. ス トロメクトール®錠ではポリ塩化ビニル，シリコ ン，ポリウレタン，エチレン酢酸ビニル製の経鼻 チューブにおいて材質による回収率の有意差は認 められなかったことから，材質の違いによる投与 量の損失への影響はないと考えられた。

次にチューブの太さの薬剤投与に与える影響に ついては，バルプロ酸ナトリウム細粒（商品名： デパケン® 細粒）のようにチューブの太さの違い により閉塞する例 ${ }^{9)}$ が報告されている。 ストロメ クトール®錠では $12 \mathrm{Fr}$ の経鼻チューブにおける 回収率は $8 \mathrm{Fr}$ に比べて有意差はないものの $12 \mathrm{Fr}$ の方が 6 例の回収率平均值は約 7\%高く, ばらつ きも小さかった。ささらに $7 \mathrm{Fr}$ のシリコン製経鼻 チューブでは投与時にチューブの閉塞が見られ， 本体チューブとジョイントチューブおよびコネク ターを繋ぐ接続管の部分の内径がより小さくなっ ており，この部分に本剤が堆積し閉塞していた. チューブの閉塞は薬剤の粒子径や懸濁状態に加え てチューブ内部の構造が大きく関与する可能性が 指摘されている ${ }^{16)}$ が 7 Fr 以下の経鼻チューブ使用 時においては閉塞に注意を要すると考えられた。 さらに，使用した経鼻チューブのうち接続管が付
属する製品はシリコン製チューブのみであり，ま たシリコンは非常に軟らかい反面, 外径に対して 内径が小さくなる (肉厚) 特徵もある ${ }^{12}$ ため, シ リコン製チューブの使用時は特に注意が必要であ る. 一方, ポリウレタンは外径に対して内径が大 きい (肉薄) 特徵があり, $\left.{ }^{15}\right)$ 本検討での材質の比較 で有意差はなかったものの一番回収率が高く, 内 径の大きさが影響していた可能性も考えられた。

次に, フラッシュ容量の検討では, ポリ塩化ビニ ル製で $12 \mathrm{Fr} 120 \mathrm{~cm}$ の経鼻チューブ（内容積 6.9 $\left.\mathrm{cm}^{3}\right)$ を使ってストロメクトール®錠を懸濁投与し た後, $5 \mathrm{~mL}$ と $20 \mathrm{~mL}$ でフラッシュ操作を行った場 合の回収率には有意な差は見られなかった。経鼻 チューブは胃瘻チューブに比べ細くて長いため, フ ラッシュ操作を行う際, 1 回量が経鼻チューブ内容 積以下の $5 \mathrm{~mL}$ で洗浄した場合に回収率が劣るので はと想定していたが, 約 6\%回収率は低いものの, 回数を重ねても同様な差で推移したが有意差はな かった．また，患者の身長などの状況により，チュー ブにたるみが出る場合もあるが, $20 \mathrm{~cm}$ の高低差の あるたるみは回収率に影響を与えなかった。

さらに 30 ○ベッドアップの有無の影響に関する 検討では, ベッドアップなしと $30^{\circ}$ のベッドアッ プともに精製水 $20 \mathrm{~mL}$ のフラッシュ操作を 1 回 行っていても, ベッドアップなしは回収率が約 9\% 有意に低下し，30ベッドアップは回収率に影響 を与えることが示唆された。 このことは, その後 メタノール $20 \mathrm{~mL}$ でフラッシュ操作を行うことで 投与量全量が回収されたことより, 経鼻チューブ 内でのイベルメクチンの滞留が回収率低下につな がったと考えられた，ストロメクトール®錠 $3 \mathrm{mg}$ 
の重さは $60 \mathrm{mg}$ であり, 95\%は添加物で形成され ている．添加物には水に不溶のものもあるが，添 加物の定量は行っていないため, 添加物がイベル メクチンの回収率に影響を与えた可能性について は不明である。今回検討を行ったチューブのフ ラッシュ容量は回収率に影響しない結果であった が，すべて $30^{\circ}$ ベッドアップで行っていたため, ベッドアップしない状況では回収率に影響を与え る可能性も考えられた。

以上より, 今回行った $5 つ の$ 検討項目において, 比較対象とした方法のイベルメクチン回収率は 86.6 92.5\%であり，イベルメクチン投与量の損 失率は約 $10 \%$ であった。これは，大谷らの実験 による最低損失率 $10 \%$ とほぼ同じであったこと から，30ベッドアップを行うことで経鼻チュー ブによる投与量の損失をなくすことが可能と考え られた. しかし, 患者の病態によってはベッドアッ プできない場合や，その他，患者のあらゆる状況 を想定することは難しく，すべての投与状況に当 てはめることはできず，そこが本検討結果の限界 である。 あくまでも本検討結果が，患者の個々の 状況を考慮した最善の経管投与方法を検討するう えでの一助となれば幸いである。

薬荗師の在宅訪問や病棟への配置が進むなか, 医療チームの一員として薬剤の特性を考慮した薬 剤師の経管投与への積極的関与は，薬剤の有効性 の確保につながり重要であると考える.

\section{引用文献}

1）石井則久, 朝比奈昭彦, 天谷雅行, 飯島正文, 石川 治, 今村英一, 大江麻里子, 大滝倫子, 加藤安彦, 金澤伸雄, 上出良一, 神崎 保, 木花 光, 小茂田 昌代, 杉山奈津子, 関根万理, 竹崎伸一郎, 田中 勝, 田村暢子, 永岡 讓, 南光弘子, 林 正幸, 牧上久仁子, 松田知子, 吉住順子, 和田康夫, 疥癄 診療ガイドライン (第 2 版), 日本皮膚科学会雑 誌, 2007, 117, 1-13.

2) Strong $M$, Johnstone $P$, Interventions for treating scabies, Cochrane Database Syst Rev, 2010, 10, 1-70.

3）小泉一馬, 大仲陽一, 竹下由紀代, 沢田 繁, 焚立 元, 原 満良, 中村圭吾, 坂下祐子, 浜名信幸,
松村憲一, 岡森和彦, 疥痽に対するストロメク トール®錠3 mg（イベルメクチン）の製造販売 後調查 - 使用成績調查 -, 新薬と臨斨, 2010, 59, 924-938.

4）大滝倫子, “疥癬対策パーフェクトガイド”, 第 1 版, 南光弘子編, 秀潤社, 東京, 2008, pp30-41.

5）大滝倫子, 谷口裕子, 牧上久仁子, 高齢者施設で の疥痽の集団発生に対するイベルメクチンの治 療効果, 臨床皮膚科, 2005, 59, 692-698.

6）田村暢子, 石井則久, 高齢者の疥噋に対するイベ ルメクチンの治療効果について, 日本皮膚科学 会雑誌, 2005, 115, 2405-2407.

7）大谷真理子, 山本陽介, 酒巻智美, 大沼亜紀, 赤木 圭太, 松田慶祐, 杉山奈津子, 宮嶋篤志, 廣田 孝司, 小茂田昌代, 簡易懸濁法の器具および手技 がストロメクトール錠の投与量に及ぼす影響, 医療薬学, 2012, 38, 78-86.

8）松田三郎, 石川茂行, 岸谷敏男, 小森俊伸, 経管栄 養チューブを用いたガストローム顆粒の通過 性の検討, 新薬と臨床, 1999, 48, 627-631.

9）末丸克矢, 川上賢哉, 市川裕規, 荒木博陽, 柴田 和彦, 二神幸次郎, 五味田裕, 小児用経鼻チュー ブの薬剤通過性, 医療薬学, 2003, 29, 337-340.

10）大谷 順, “NSTのための経腸栄養実践テクニッ ク”, 佐々木雅也編, 昭林社, 東京, 2007, pp88-93.

11）雨海照祥, 井上善文, 大谷 順, 大村健二, 小山 論, 桜井洋一, 滋賀英敏, 正田良介, 曺 英樹, 中村 卓郎, 福田能啓, 宮田 剛, 山内 健, “静脈経腸 栄養ガイドライン - 静脈経腸栄養を適正に実 施するためのガイドラインー", 第 3 版, 日本静脈 経腸栄養学会編, 南江堂, 東京, 2013, pp115-116.

12）井上善文, “日本静脈経腸栄養学会 静脈経腸栄 養ハンドブック”, 日本静脈経腸栄養学会編, 南 光堂, 東京, 2011, pp212-218.

13）倉田なお み, “内服薬 経管投与ハンドブック”, 第 2 版, 藤島一郎監, ビほう, 東京, 2006, pp2-47.

14）石渡一夫, “静脈経腸栄養年鑑2011 製剤·器具一 覧”, 第 7 巻, 石渡一夫編, 株式会社ジェフコーポ レーション, 2011, pp161-166.

15）小茂田昌代, “簡易懸濁法Q\&A Part2-実践編”, 簡 易懸濁法研究会編, じほう, 東京, 2009, pp99-100.

16）平泉達哉, 安保忠明, 笹原秀明, 中鉢明彦, 経管投 与時のチューブ内閉塞予防に対する流動性ゼ リーの有用性, 日本病院薬剂師会雑誌, 2004, 40, 981-984. 